\title{
REDESIGN DAN PEMETAAN JARINGAN WLAN BERDASARKAN CAKUPAN AREA DI KANTOR DINAS PENDIDIKAN KAYUAGUNG
}

\author{
Irwansyah $^{1}$, Helda Yudiastuti ${ }^{2}$ \\ Dosen Universitas Bina Darma ${ }^{1,2}$ \\ Jalan Jenderal Ahmad Yani No.3 Palembang \\ Sur-el : irwansyah@binadarma.ac.id ${ }^{1}$, helda.yudiastuti@binadarma.ac.id ${ }^{2}$
}

\begin{abstract}
Wi-Fi technologies are widely used generally using IEEE 802 wireless standardization. $11 \mathrm{a} / \mathrm{b} / \mathrm{g}$ which works at a frequency of $2.4 \mathrm{GHz}$. These devices are found in almost all places, such as in offices - Government offices, private companies, entertainment venues, and educational venues. Currently the need for Wi-Fi (wireless fidelity) is very much needed, because nowadays many gadget devices that have been equipped with Wi-Fi so that with Wi-Fi Everyone can access the Internet everywhere. Based on the results of a field survey conducted on the WLAN network in the office of the Dinas Pendidikan Kayuagung in South Sumatera, from all computer units in the office is connected to the Internet through a network cable or wireless network, that the wireless network felt is still less optimal because there are some areas that are not covered or affordable by the Wi-Fi network. The researcher aims to redesign and rebrand Wi-Fi networks based on the scope of the area to be more optimal. While the research method to be used is the method PPDIOO (Prepare Plan Design Implement Operate and Optimize).
\end{abstract}

Keywords: Wi-Fi (wirelesss fidelity), WLAN, Internet

\begin{abstract}
Abstrak : Teknologi Wi-fi yang banyak digunakan secara umum menggunakan standarisasi wireless IEEE 802. $11 \mathrm{a} / \mathrm{b} / \mathrm{g}$ yang bekerja pada frekuensi $2.4 \mathrm{GHz}$. Perangkat ini banyak dijumpai hampir di semua tempat, seperti di kantor - kantor pemerintahan, perusahaan swasta, tempat tempat hiburan, dan tempat pendidikan. Saat ini kebutuhan akan Wi-Fi (wirelesss fidelity) sangat di perlukan, karena sekarang ini banyak perangkat gadget yang telah dilengkapi dengan Wi-Fi sehingga dengan Wi-Fi tersebut semua orang dapat mengakses internet dimanapun. Berdasarkan hasil survey lapangan yang dilakukan pada jaringan WLAN di Kantor Dinas Pendidikan Kayuagung Sumatera Selatan, Dari semua unit komputer pada Kantor Dinas tersebut terkoneksi ke internet melalui jaringan kabel maupun jaringan wireless, bahwa jaringan wireless dirasakan masih kurang optimal karena ada beberapa area yang tidak tercakup atau terjangkau oleh jaringan Wi-Fi tersebut. Peneliti ini bertujuan untuk meredesain dan memetakaan ulang jaringan Wi-Fi berdasarkan cakupan area agar lebih optimal. Sedangkan metode penelitian yang akan digunakan yaitu metode PPDIOO (Prepare Plan Design Implement Operate and Optimize).
\end{abstract}

Kata kunci: Wi-Fi (wirelesss fidelity), WLAN, Internet

\section{PENDAHULUAN}

Saat ini kebutuhan akan Wi-Fi (wirelesss fidelity) sangat di perlukan, karena saat ini banyak perangkat gadget yang telah dilengkapi dengan Wi-Fi sehingga dengan Wi-Fi tersebut semua orang dapat mengakses internet dimanapun. Wireless Local Area Network
(WLAN) adalah system komunikasi data yang fleksibel, dapat diimplementasikan sebagai perpanjangan atau sebagai alternative pengganti untuk jaringan kabel LAN [1]. Teknologi Wi-fi yang banyak digunakan secara umum menggunakan standarisasi wireless IEEE 802. $11 \mathrm{a} / \mathrm{b} / \mathrm{g}$ yang bekerja pada frekuensi $2.4 \mathrm{GHz}$. Perangkat ini banyak dijumpai hampir di semua 
tempat, seperti di kantor-kantor pemerintahan, perusahaan swasta, tempattempat hiburan, dan tempat pendidikan.

Penelitian ini dilakukan pada jaringan WLAN di Kantor Dinas Pendidikan Kayuagung Sumatera Selatan, Dari semua unit komputer pada Kantor Dinas tersebut terkoneksi ke internet melalui jaringan kabel maupun jaringan wireless. Hal itu dikarenakan banyaknya tugastugas atau pekerjaan di setiap bagian Kantor Dinas Pendidikan Kayuagung yang memerlukan media internet. Berdasarkan hasil survey lapangan bahwa jaringan wireless dirasakan masih kurang optimal karena ada beberapa area yang tidak tercakup atau terjangkau oleh jaringan Wi-Fi tersebut. Dari identifikasi permasalahan itu maka peneliti bertujuan untuk meredesain dan memetakaan ulang jaringan Wi-Fi berdasarkan cakupan area yang lebih optimal. Dan juga agar nantinya dapat memberikan hasil yang baik dan nyaman dalam pengguna jaringan hotspot wi-fi.

Adapun metode penelitian dari redesain jaringan WLAN ini menggunakan metode PPDIOO (Prepare Plan Design Implement Operate and Optimize). Formula siklus hidup perencanaan jaringan PPDIOO menjadi enam fase : Persiapan, Perencanaan, Desain, Implementasi, Operasi dan Optimasi [2].

\section{METODOLOGI PENELITIAN}

\subsection{Instrumen Penelitian}

Dalam melaksanakan penelitian ini, dibutuhkan instrument atau alat serta bahan yang digunakan untuk merancang dan membangun jaringan komputer yang dibutuhkan. Instrumen atau aat dan bahan dalam penelitian ini meliputi; (a). Laptop \& Handphone, berfungsi sebagai receiver yang menerima pancaran sinyal gelombang radio dari access point, (b). Access Point, berfungsi sebagai transmitter yang memancarkan sinyal gelombang radio, (c) Wifi Analizer, berfungsi untuk scanning jaringan $\mathrm{Wi}$ $f i$, dan (d) Meteran, digunakan untuk mengukur jarak dan ketinggian access point.

\subsection{Teknologi Dasar WLAN}

WLAN adalah teknologi komunikasi data menggunakan gelombang radio yang dirancang untuk menggantikan sistem LAN kabel dengan kinerja yang sepadan. Dengan berkembangnya teknologi terdapat beberapa standar yang masih termasuk standar keluarga besar LAN IEEE 802.x, yaitu 802.11a, 802.11b, $802.11 \mathrm{~g}, 802.11 \mathrm{n}$ dan masih terus dikembangkan sampai saat ini. Perbedaan yang mendasar antar standar tersebut mencakup pita frekuensi radio yang digunakan, teknologi modulasi dan kecepatan transfer yang dihasilkan [3].

\subsection{Standarisasi Wireless LAN}

Awal mula produk utama WLAN berawal pada tahun 1997 oleh Institute of Electrical and electronics Engineers (IEEE) dengan standar 802.11 mengalami peningkatan dengan penambahan dokumen berdasarkan surat yang ditunjuk mengikuti nama 802.11 seperti 802.11 , 802.11a, atau 802.11g. Adapun ahiran huruf dari varian tersebut mewakili kelompok tugas yang mendefenisikan eksensi masing-masing standar. Peningkatan ini membawa kecepatan data dan fungsi yang mengarah pada perkembangan yang 
cepat dari WLAN. Pada tabel 2.1 berikut adalah spesifikasi IEEE 802.11 dengan singkat menjelaskan tambahaan yang berhubungan dengan data rate (WLAN physical layer) [4], Spesifikasi Standar IEEE 802.11 adalah :

\section{a. WLAN 802.11a}

Pada tahun 1999, IEEE mengeluarkan standar 802.11 a yang beroperasi pada pita 5 $\mathrm{GHz}$, standar ini menggunakan skema modulasi yang disebut orthogonal Frequency Division Multiplexing (OFDM) dengan kecepatan transmisi data mencapai 54 Mbps. Keuntungan utama dari standar ini adalah kapasitasnya yang cukup tinggi menjadikan standar ini sebagai pilihan yang tepat untuk mendukung aplikasi yang membutuhkan performa tinggi, seperti streaming video. Kekurangan dari standar ini adalah terbatasnya cakupan area pancarnya karena menggunakan pita frekuensi 5 GHz. Pita ini hanya dapat mencakup area tidak lebih dari 50 meter pada berbgai fasilitas, akibatnya standar ini mmerlukan AP yang lebih banyak [5].

\section{b. WLAN 802.11b}

Standar WLAN yang paling umum digunakanpada saat adalah standar 802.11 b yang menggunakan frekuensi $2,4 \mathrm{GHz}$ dengan spesifikasi; a) Pita frekuensi 2.40 - $2.4835 \mathrm{GHz}$, b) 13 kanal (ETSI) atau 11 kanal (FCC) dengan 3 kanal yang tidak saling overlap 1, 7, 13 untuk ETSI dan kanal 1, 6, dan 11 untuk FCC, $c$ ) Lebar pita frekuensi $22 \mathrm{MHz}$ dengan jarak separasi 5 $\mathrm{MHz}, d)$ Data rate per kanal sesuai dengan modulasi yang digunakan dan bergantung jarak transmisi yaitu; 1 Mbps (DBPSK), 2 Mbps (DQPSK), 5.5 Mbps (CCK) dan 5.5 Mbps
(CCK) dan e) Teknik modulasi Direct-Sequence Spread Spectrum (DSSS) dengan data baseband (PPDU) ditebar dengan PN code atau chip. Blok DSSS seperti pada Gambar 1.

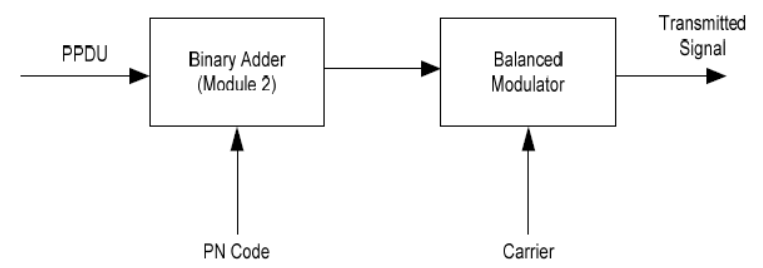

Gambar 1. Blok Modulasi DSSS [6]

\section{c. WLAN 802.11g}

Standar 802.11g dikeluarkan pada bulan juni 2013. Standar ini beroperasi pada frekuensi yang sama seperti standar 802.11 b yaitu pada pita $2.4 \mathrm{GHz}$ hingga $2.497 \mathrm{GHz}$. Tetapi standar ini menggunakan teknik modulasi OFDM yang digunakan pada standar 802.11a. kombinasi dari fitur ini menghasilkan infrastuktur yang lebih cepat, lebih murah, serta koneksi yang lebih luas. Keunggulan dari standar ini adalah memiliki kompatibilitas dengan standar $802.11 \mathrm{~b}$, dimana kita hanya perlu meng-upgrade AP pada jaringan $802.11 \mathrm{~b}$ ke standar $802.11 \mathrm{~g}$. tetapi peralatan pada standar $802.11 \mathrm{~b}$ tidak memahami transmisi pada peralatan 802.11g karena perbedaan teknik modulasi pada kedua standar. Sehingga saat peralatan jaringan $802.11 \mathrm{~b}$ digunakan pada lingkungan standar 802.11g terdapat berbagai keterbatasan. Kerugian lainnya dari stndar ini adalah adanya interferensi karena standar ini menggunakan frekuensi $2.4 \mathrm{GHz}$ yang sarat dengn interferensi stasiun yang dapat menyebabkan seluruh jaringan terganggu. Hal ini dapat diatasi dengan menggunakan cincin (ring) ganda dengan salah atu cincin back-up 
seperti yang dipakai pada jaringan ring berteknoogi FDDI [7].

Tabel 1. Kategori Berdasarkan Kualitas Sinyal

\begin{tabular}{cc}
\hline $\begin{array}{c}\text { Kategori } \\
\text { Kualitas Sinyal }\end{array}$ & $\begin{array}{c}\text { Kualitas Sinyal } \\
(\mathbf{d B m})\end{array}$ \\
\hline Excellent & -10 to $-57 \mathrm{dBm}(75-$ \\
& $100 \%)$ \\
Good & -58 to $-75 \mathrm{dBm}(40-$ \\
& $74 \%)$ \\
Fair & -76 to $-85 \mathrm{dBm}(20-$ \\
& $39 \%)$ \\
Poor & -86 to $-95 \mathrm{dBm}(0-$ \\
& $19 \%)$ \\
\hline
\end{tabular}

\section{d. Topologi Wireless LAN}

Mode Ad-Hoc adalah suatu kondisi jaringan wireless yang tidak menggunakan access point. Artinya, antar client langsung terkoneksi satu dengan yang lainnya. Jika merasa asing dengan istilah $A d-H o c$, mungkin istilah Peer-to-peer dapat lebih mempermudah mengenali koneksi Ad-Hoc. Prinsip kerjanya sama saja dengan Peer-to-peer. Disini setiap client akan saling terkoneksi secara langsung [8].

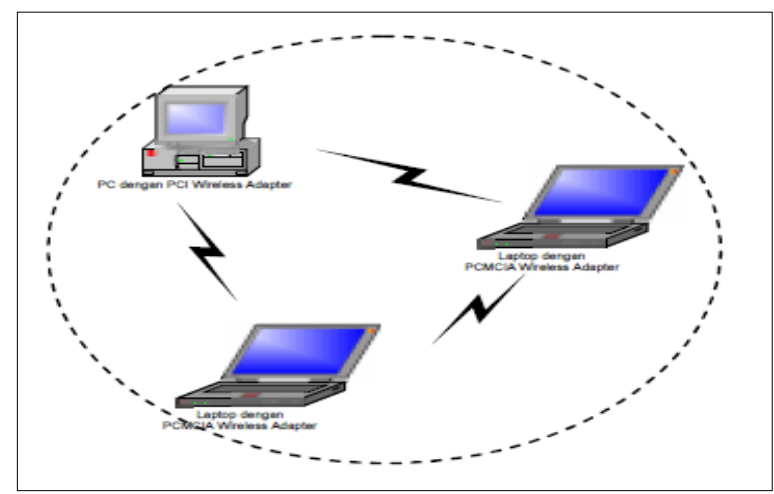

Gambar 2. Topologi Mode Ad-Hoc

Model infrastructure adalah kondisi suatu jaringan dengan menggunakan suatu titik pusat yaitu access point. Semua client terhubung ke jaringan harus terkoneksi ke access point terlebih dahulu, baru kemudian dapat mengakses resource dari network/client lain yang ada. Untuk topologi infrastruktur, tiap PC mengirim dan menerima data dari sebuah titik akses, yang dipasang di dinding atau langit-langit berupa sebuah kotak kecil berantena. Saat titik akses menerima data, ia akan mengirimkan kembali sinyal radio tersebut (dengan jangkauan yang lebih jauh) ke PC yang berada di area cakupannya, atau dapat mentransfer data melalui jaringan Ethernet kabel. Titik akses pada sebuah jaringan infrastruktur memiliki area cakupan yang lebih besar [8].

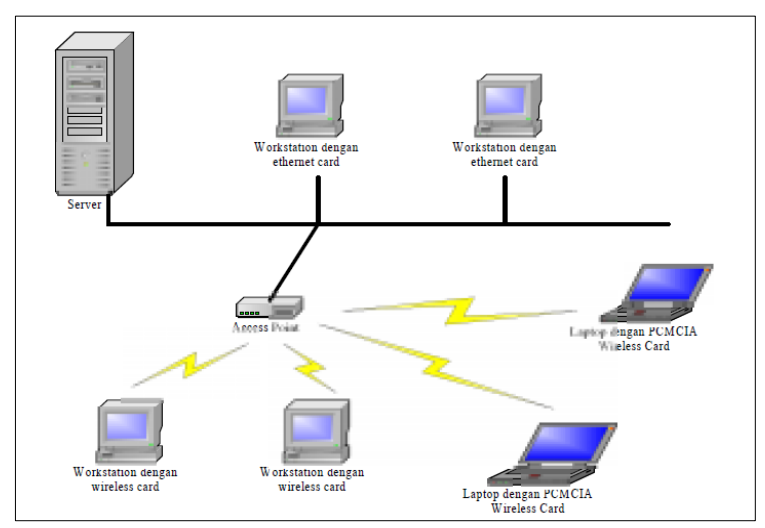

Gambar 3. Model Infrastruktur

\section{e. Komponen Wireless}

Ada beberapa komponen yang dibutuhkan dalam sebuah jaringan wireless atau nirkabel terdiri atas empat komponen utama, yakni wireless card, wireless router atau wireless access point, extension point, koneksi internet dan antenna [9].

a) Wireless Card, Wireless card ini digunakan untuk menagkap sinyal yang dikirim ke bagian ini sehingga diperoleh penggunaan yang lebih lengkap bila dibandingkan dengan beberapa penggunaan lainnya.

b) Wireless Router atau wireless access point, adalah perangkat yang berperan penting 
dalam sebuah jaringan wireless, bertugas mengatur dan menghubungkan koneksi beberapa peralatan Wi- Fi. Wireless router ini dikenal juga dengan nama wireless broadband router atau access point.

\section{f. Jaringan Komputer}

Jaringan komputer (computer networks) adalah himpunan interkoneksi sejumlah komputer autonomous. Kata "autonomous" mengandung pengertian bahwa komputer tersebut memiliki kendali atas dirinya sendiri. Jaringan komputer dapat dikatakan sebagai kumpulan beberapa buah komputer yang terhubung satu sama lain dan dapat saling berbagi resources [10].

Sebuah jaringan lebih dari sekedar pertukaran data antara dua atau beberapa komputer yang terhubung oleh kabel (atau koneksi radio). Sehingga antar kedua komputer tersebut bisa ada pertukaran komunikasi. Ini karena komputer sendiri bisa melakukan pertukaran komunikasi [11].

\section{HASIL DAN PEMBAHASAN}

\subsection{Topologi Jaringan WLAN di Kantor Dinas Pendidikan Kayuagung.}

Kantor Dinas Pendidikan Kayuagung menggunakan layanan koneksi Internet IndiHome dari PT. TELKOM. Koneksi Internet dari IndiHome dihubungkan dengan router MikroTik yang dihubungkan dengan 3 buah switch 16 port yang kemudian dihubungkan dengan 8 buah hotspot/Wi-Fi yang tersebar pada setiap ruangan. Gambar 4 menunjukan topologi jaringan WLAN pada Dinas Pendidikan Kayuagung. Gambar 5 menunjukkan denah ruang Kantor Dinas Pendidikan Kayuagung dengan tata letak penempatan Wi-fi.

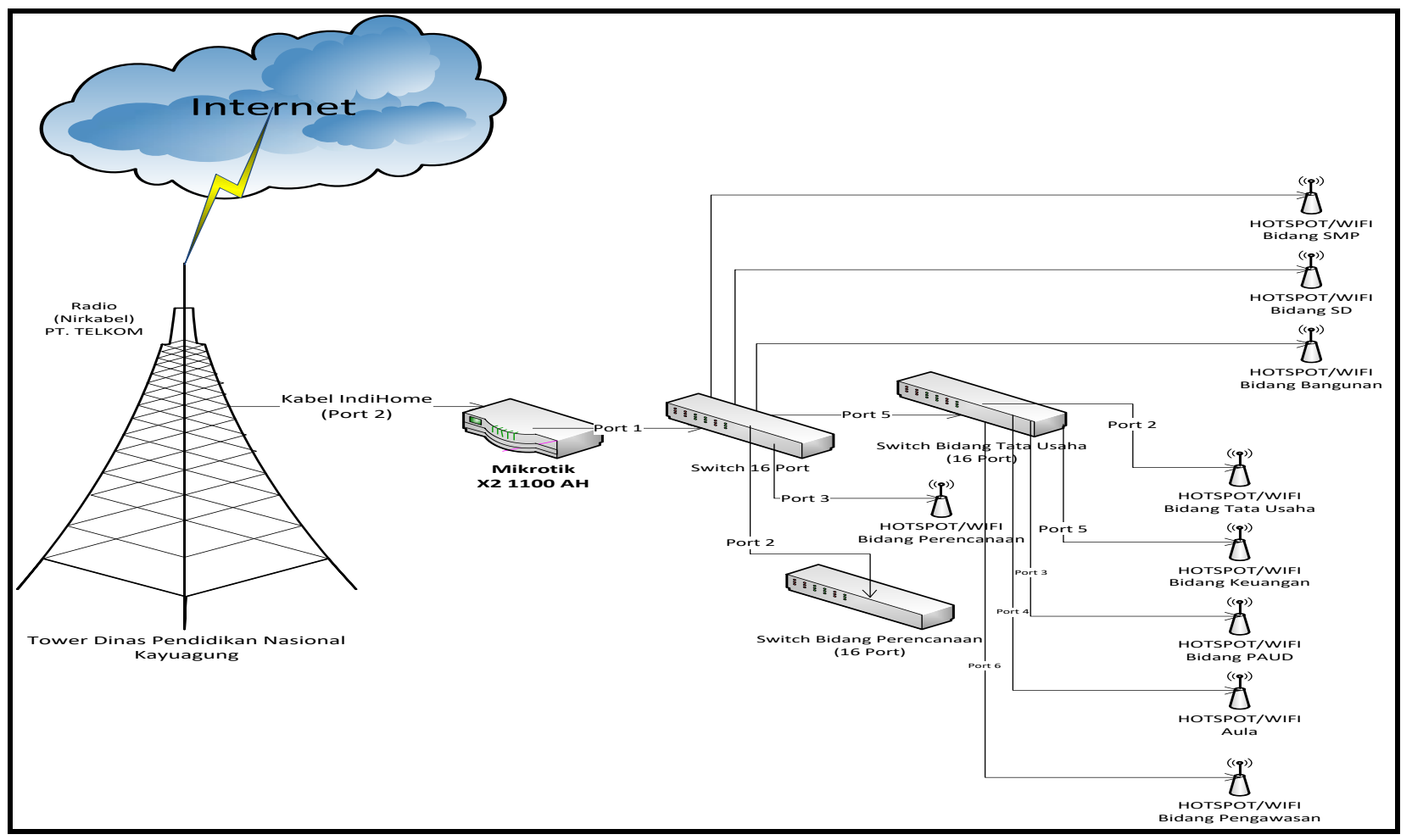

Gambar 4. Topologi WLAN Diknas Kayuagung 


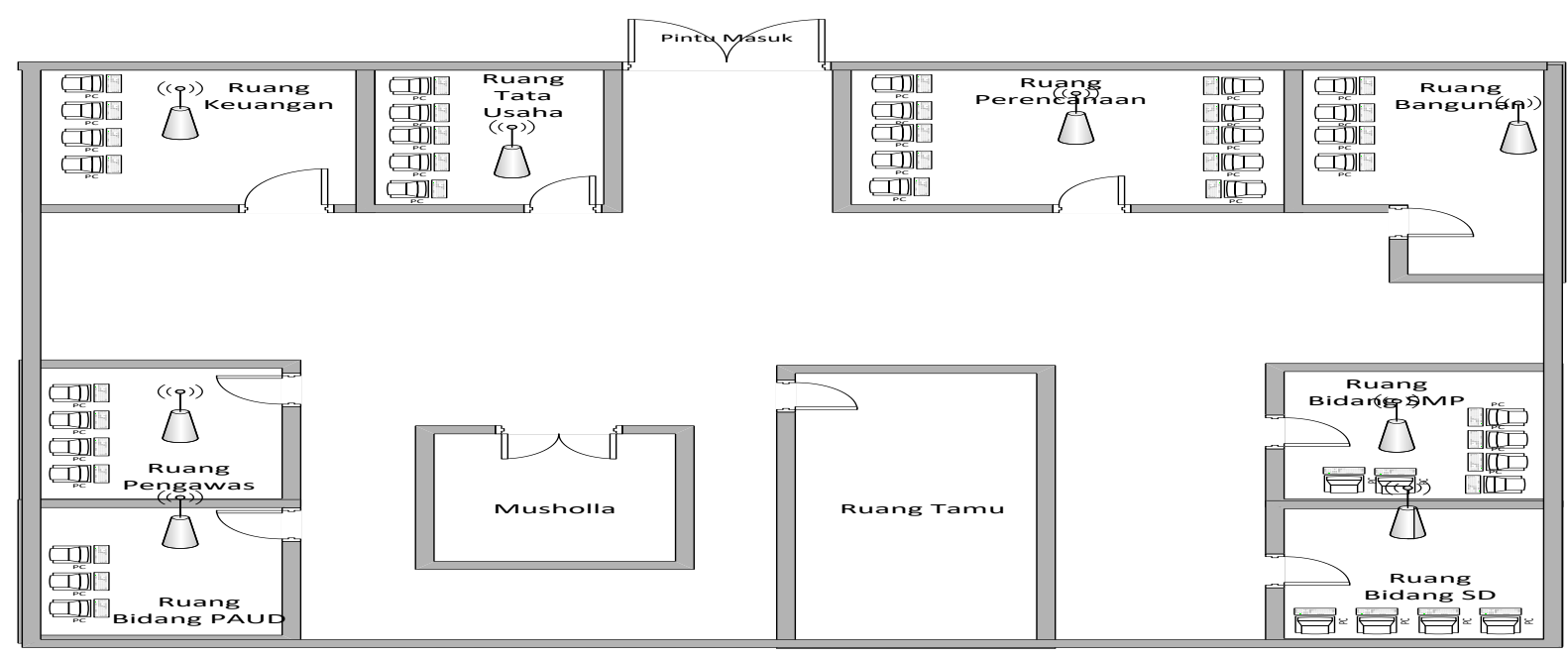

Gambar 5. Denah Ruangan \& Letak Wi-Fi

\subsection{Pengukuran Sinyal Wi-Fi}

Berikut pengukuran sinyal Wi-Fi pada setiap ruangan . Pengukuran dilakukan dari jarak 5 meter dan 25 meter antara wifi dan user. Pengukuran kekuatan sinyal $W i-F i$ ini dengan bantuan Software Wifi Analyzer melalui android.

\subsubsection{Pengukuran Sinyal Wifi Pada Ruang Keuangan Dan Tata Usaha}

Pengukuran pertama dilakukan untuk wifi pada ruang keuangan dan ruangan tata usaha, pengukuran dilakukan dengan jarak 5 meter dan 25 meter. Pengukuran dua ruangan ini dilakukan secara bersamaan dikarenakan dua ruangan yang berdekatan. Hasil pengukuran dapat dilihat pada gambar 6 dan gambar 7.

\section{Diknas Keuangan (30:b5:c2:f8:4b:6c) \\ $-56 \mathrm{dBm}$ CH $102457 \mathrm{MHz} \quad 6.1 \mathrm{~m}$}

$2447-2467(20 \mathrm{MHz})$ TP LINK TE

过 [WPA2-PSK-TKIP+CCMP][ESS][WPS

Speedy Instan@wifi.id (30:b5:c2:f8:4b:6d)

$-57 \mathrm{dBm}$ CH $102457 \mathrm{MHz} \quad 6.9 \mathrm{~m}$

$2447-2467(20 \mathrm{MHz})$ TP LINK TE

. . [ESS]

Diknas Tata Usaha (00:25:9c:c1:30:17)

$-65 \mathrm{dBm}$ CH 11 2462MHz 17.2m

2452 - $2472(20 \mathrm{MHz})$ CISCO LINK . [ESS]
Diknas Tata Usaha (00:25:9c:c1:30:17)

$-56 \mathrm{dBm}$ CH 11 2462MHz $6.1 \mathrm{~m}$

2452-2472 (20MHz) CISCO LINK

面 [ESS]

Diknas Keuangan (30:b5:c2:88:4b:6c)

$-65 \mathrm{dBm}$ CH $102457 \mathrm{MHz} 17.3 \mathrm{~m}$

2447-2467 (20MHz) TP LINK TE

?. [WPA2-PSK-TKIP+CCMP][ESS][WPS]

Speedy Instan@wifi.id (30:b5:c2:f8:4b:6d)

$-66 \mathrm{dBm}$ CH $102457 \mathrm{MHz}$ 19.4m

\section{7 - 2467 (20MHz) TP LINK TE}

苗 [ESS]

Gambar 7. Pengukuran pada Ruangan

Diknas Tata Usaha

Pada gambar 6. terlihat SSID Wifi Dinas

Keuangan dengan kekuatan sinyal sebesar -56 $\mathrm{dBm}$ dengan jarak pengukuran 6.1 meter. Sedangkan untuk SSID Wifi Diknas Tata Usaha kekuatan sinyalnya sebesar $-65 \mathrm{dBm}$ pada Jarak 17,2 meter. Untuk gambar 7. SSID Wifi Diknas Tata Usaha dengan kekuatan sinyal sebesar -56 $\mathrm{dBm}$ dengan jarak pengukuran 6.1 meter. Sedangkan untuk SSID Wifi Dinas Keuangan kekuatan sinyalnya sebesar $-65 \mathrm{dBm}$ pada Jarak 17,3 meter.

\section{Gambar 6. Pengukuran pada Ruangan Diknas Keuangan}




\subsubsection{Pengukuran Sinyal Wifi Pada Ruang} Perencanaan Dan Bangunan

Pada pengukuran yang kedua dilakukan pada dua ruangan yang juga berdekatan yaitu ruang perencanaan dan ruang bangunan. Pengukuran dilakukan pada jarak 5 meter dari wifi pada ruangan perencanaan dan 25 meter dari ruangan bangunan. Gambar 8 menunjukan hasil pengukuran pada ruangan Perencanaan.

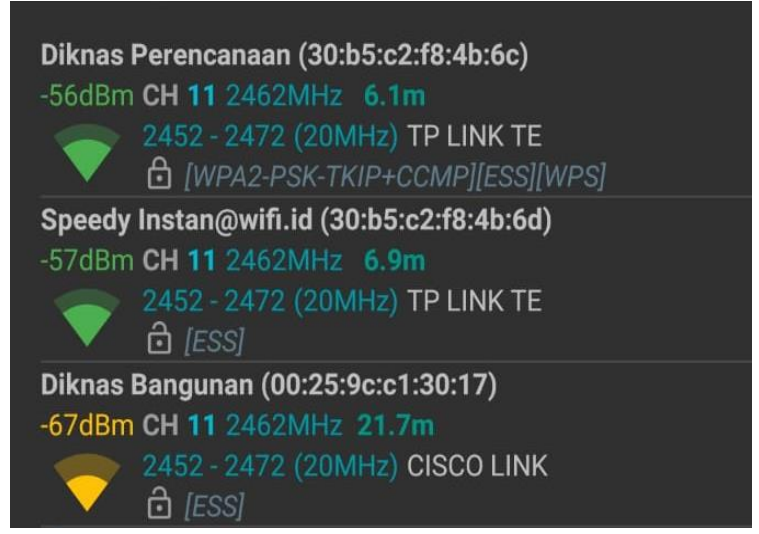

\section{Gambar 8. Pengukuran pada Ruangan Perencanaan}

Diknas Bangunan (00:25:9c:c1:30:17) $-55 \mathrm{dBm}$ CH $112462 \mathrm{MHz} 5.4 \mathrm{~m}$

$2452-2472(20 \mathrm{MHz})$ CISCO LINK .] [ESS]

Diknas Perencanaan (30:b5:c2:f8:4b:6c) $-69 \mathrm{dBm}$ CH $112462 \mathrm{MHz} 27.3 \mathrm{~m}$

$2452-2472(20 \mathrm{MHz})$ TP LINK TE [. [WPA2-PSK-TKIP+CCMP][ESS][WPS

\section{Gambar 9. Pengukuran pada Ruangan Bangunan}

Pada gambar 8. terlihat SSID Wifi Dinas Perencanaan dengan kekuatan sinyal sebesar -56 $\mathrm{dBm}$ dengan jarak pengukuran 6.1 meter. Sedangkan untuk SSID Wifi Diknas Bangunan kekuatan sinyalnya sebesar $-67 \mathrm{dBm}$ pada Jarak 21,7 meter. Ini disebabkan jarak antara kedua Wifi yang berjauhan letaknya. Sedangakn untuk gambar 9. SSID Wifi Diknas Bangunan dengan kekuatan sinyal sebesar $-55 \mathrm{dBm}$ dengan jarak pengukuran 5.4 meter. Dan untuk SSID Wifi Dinas Perencanaan kekuatan sinyalnya sebesar $69 \mathrm{dBm}$ pada Jarak 27,3 meter.

\subsubsection{Pengukuran Sinyal Wifi Pada Ruang Pengawas Dan Bidang PAUD}

Pada pengukuran yang ketiga dilakukan pada dua ruangan yang juga berdekatan yaitu ruang Ruang Pengawas Dan Bidang PAUD. Pengukuran dilakukan pada jarak 5 meter dari wifi pada ruangan pengawas dan Bidang PAUD, serta dengan jarak 25 meter dari kedua ruangan tersebut.

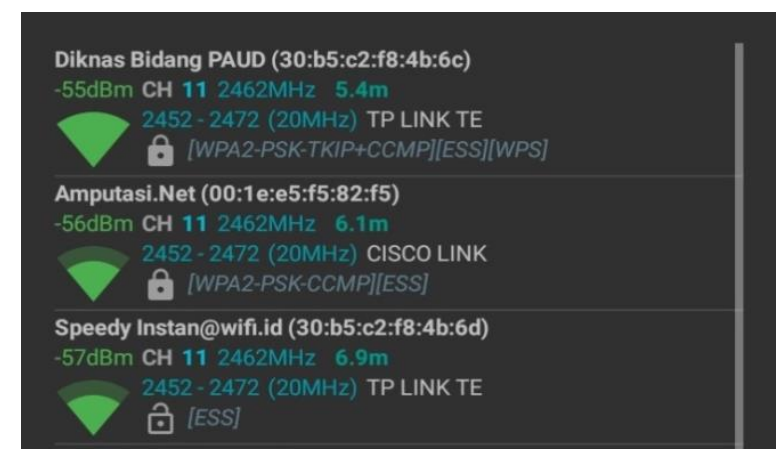

\section{Gambar 10. Pengukuran pada Ruangan Bidang PAUD Jarak 5 Meter}

Pada gambar 10. terlihat SSID Wifi Bidang PAUD dengan kekuatan sinyal sebesar $-55 \mathrm{dBm}$ dengan jarak pengukuran 5.4 meter. Sedangkan untuk pengukuran yang kedua dengan jarak 21.7 meter dari titik Wifi kekuatan sinyal $-67 \mathrm{dBm}$ yang dapat dilihat pada gambar 11 .

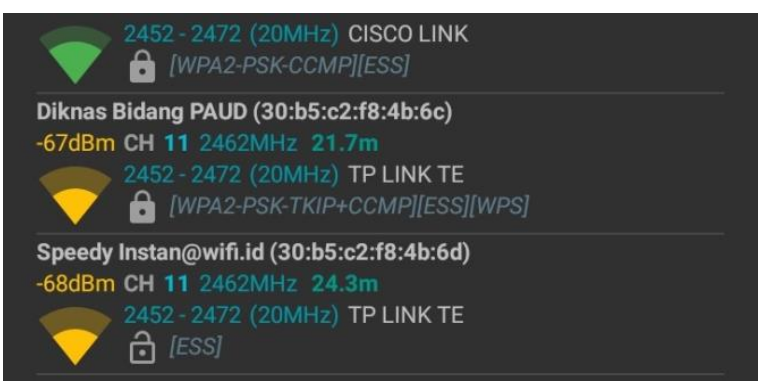

\section{Gambar 11. Pengukuran pada Ruangan Bidang PAUD}




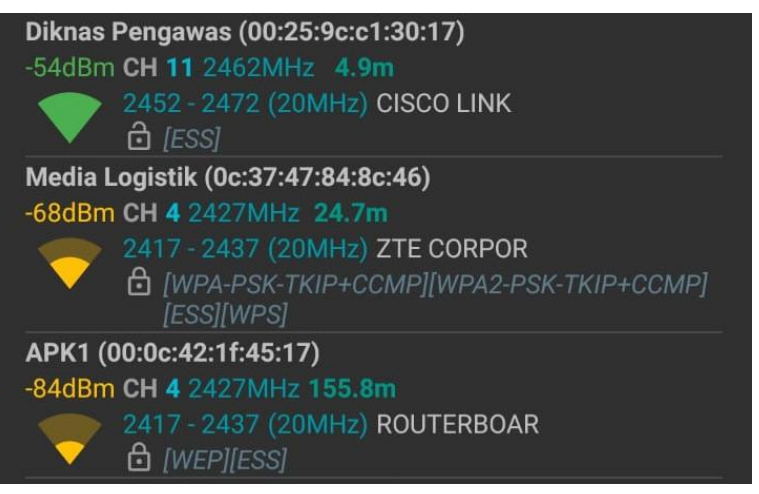

Gambar 12. Pengukuran pada Ruangan Pengawas pada Jarak 5 Meter

Pada gambar 12. hasil pengukuran pada Wifi Ruangan Pengawas dengan jarak 5 meter, kekuatan sinyal yang didapat sebesar $-54 \mathrm{dBm}$.

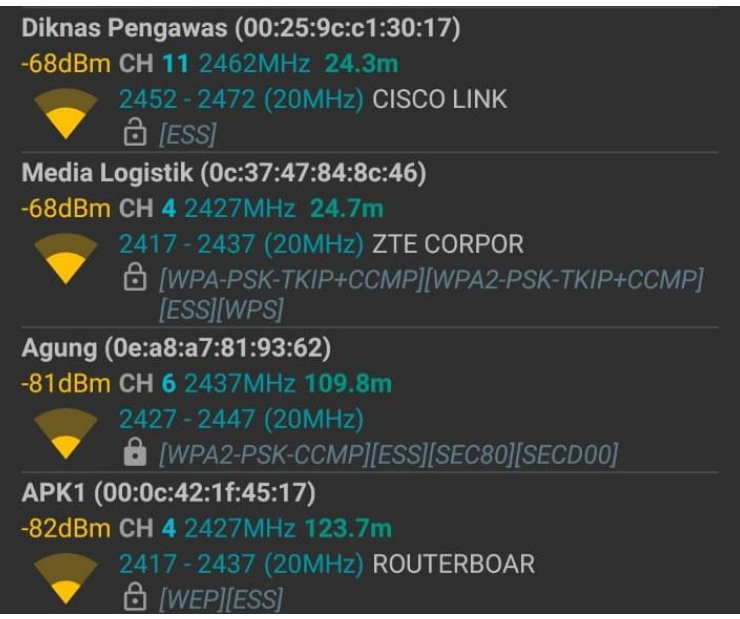

Gambar 13. Pengukuran pada Ruangan Pengawas pada Jarak 20 Meter

Dari gambar 13. merupakan hasil pengukuran pada Wifi Ruangan Pengawas dengan jarak 20 meter, kekuatan sinyal yang didapat sebesar $-68 \mathrm{dBm}$.

\subsubsection{Pengukuran Sinyal Wifi Pada Ruang Bidang SD Dan Bidang SMP}

Pada pengukuran yang berikut dilakukan pada dua ruangan yang juga berdekatan yaitu ruang bidang SD dan ruang Bidang SMP. Pengukuran dilakukan pada jarak 5 meter dan 25 meter dari wifi pada kedua ruang tersebut.

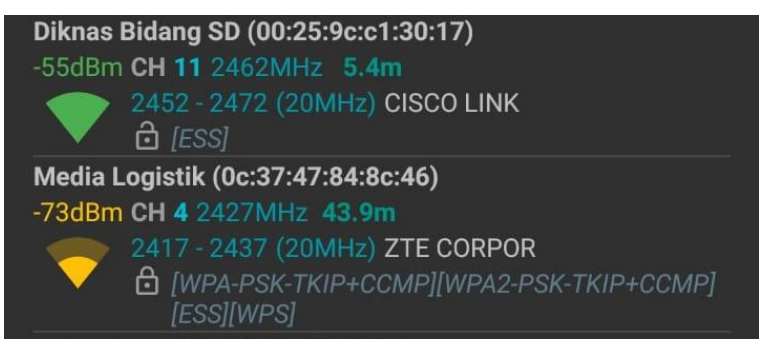

\section{Gambar 14. Pengukuran pada Ruangan Bidang SD pada Jarak 5 Meter}

Dari gambar 14. merupakan hasil pengukuran pada Wifi Ruangan Pengawas dengan jarak 5 meter, kekuatan sinyal yang didapat sebesar $-55 \mathrm{dBm}$.

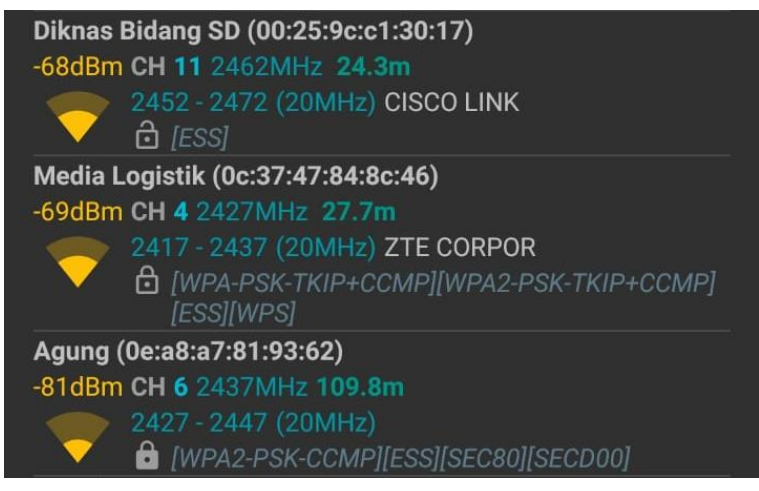

Gambar 15. Pengukuran pada Ruangan Bidang SD pada Jarak 24 Meter

Pada gambar 15. merupakan hasil pengukuran pada Wifi Ruangan Bidang SD dengan jarak 24 meter, kekuatan sinyal yang didapat sebesar $-68 \mathrm{dBm}$.

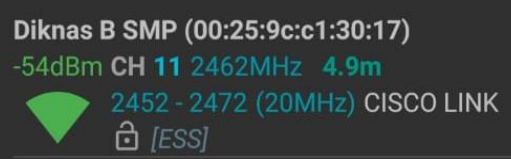

\section{Gambar 16. Pengukuran pada Ruangan} Bidang SMP pada Jarak 5 Meter

Dari gambar 16. merupakan hasil pengukuran pada Wifi Ruangan Bidang SMP dengan jarak 5 meter, kekuatan sinyal yang didapat sebesar $-54 \mathrm{dBm}$. 


\section{Wong_kayo_lamo (84:c9:b2:55:5e:87)}

$-66 \mathrm{dBm}$ CH 11 2462MHz 19.3m

$2452-2472(20 \mathrm{MHz})$ D LINK INT

Diknas B SMP (00:25:9c:c1:30:17)

$-67 \mathrm{dBm}$ CH 11

$2452-2472(20 \mathrm{MHz})$ CISCO LINK

wr_print (20:aa:4b:40:a9:2f)

$-67 \mathrm{dBm}$ CH 6

$2427-2447(20 \mathrm{MHz})$ CISCO LINK

Gambar 17. Pengukuran pada Ruangan

Bidang SMP pada Jarak 20 Meter

Dari gambar 17. merupakan hasil pengukuran pada Wifi Ruangan Bidang SMP dengan jarak 20 meter, kekuatan sinyal yang didapat sebesar $-67 \mathrm{dBm}$.

\subsection{Kategori Berdasarkan Kualitas Sinyal}

Berdasarkan hasil pengukuran sinyal Received Signal Strength Indication (RSSI) wifi yang dilakukan peneliti pada jaringan wireless di Kantor Dinas Pendidikan Nasional Kabupaten Ogan Komering Ilir Kayuagung dengan menggunakan Software Wifi Analyzer dapat dikategorikan berdasarkan kualitas sinyal seperti terlihat pada tabel 2 yang menunjukkan bahwa pengukuran pada jarak 5 meter dari letak Wifi pada masing - masing ruangan menghasilkan sinyal yang baik yaitu Excelent ini dikarenakan pengukuran dilakukan didalam ruangan yang tidak ada penghalang seperti dinding yang tebal ataupun tembok. Sedangkan untuk pengukuran pada jarak 20 - 25 meter dari jarak Wifi, kekuatan sinyal yang didapat juga masih baik.

\subsection{Redesain WLAN}

Hasil penelitian ini dilakukan redesain dan Pemetaan usulan jaringan WLAN berdasarkan hasil pengamatan dan pengukuran di lapangan. Ada beberapa penambahan Access point diantaranya 1 (satu) di Ruang Tamu, 2 (dua) di koridor antar ruangan kerja. Kemudian ada beberapa Access Point yang diubah letaknya, seperti pada ruangan Tata Usaha, Ruang Bangunan, Ruang Bidang PAUD dan Ruang Bidang SD.

Tabel 2. Hasil Pengukuran Sinyal Wifi Berdasarkan Kategori Kualitas Sinyal

\begin{tabular}{|c|c|c|c|}
\hline $\begin{array}{c}\text { Nama } \\
\text { Ruangan }\end{array}$ & $\begin{array}{c}\text { Jarak } \\
\text { (Meter) }\end{array}$ & $\begin{array}{c}\text { RSSI } \\
(\mathrm{dBm})\end{array}$ & Kualitas \\
\hline \multirow{2}{*}{ Keuangan } & 5 & $-56 \mathrm{dBm}$ & Excellent \\
\hline & 25 & $-65 \mathrm{dBm}$ & Good \\
\hline \multirow[t]{2}{*}{ Tata Usaha } & 5 & $-56 \mathrm{dBm}$ & Excellent \\
\hline & 25 & $-65 \mathrm{dBm}$ & Good \\
\hline \multirow[t]{2}{*}{ Perencanaan } & 5 & $-56 \mathrm{dBm}$ & Excellent \\
\hline & 25 & $-69 \mathrm{dBm}$ & Good \\
\hline \multirow[t]{2}{*}{ Bangunan } & 5 & $-55 \mathrm{dBm}$ & Excellent \\
\hline & 25 & $-67 \mathrm{dBm}$ & Good \\
\hline \multirow[t]{2}{*}{ Pengawas } & 5 & $-54 \mathrm{dBm}$ & Excellent \\
\hline & 25 & $-68 \mathrm{dBm}$ & Good \\
\hline Bidang & 5 & $-55 \mathrm{dBm}$ & Excellent \\
\hline PAUD & 25 & $-67 \mathrm{dBm}$ & Good \\
\hline Bidang & 5 & $-54 \mathrm{dBm}$ & Excellent \\
\hline SMP & 25 & $-67 \mathrm{dBm}$ & Good \\
\hline \multirow[t]{2}{*}{ Bidang SD } & 5 & $-55 \mathrm{dBm}$ & Excellent \\
\hline & 25 & $-68 \mathrm{dBm}$ & Good \\
\hline
\end{tabular}

\section{KESIMPULAN}

Pengukuran dilakukan pada semua ruangan di Kantor Dinas Pendidikan Kayuagung yang terdapat titik hostspot, pengukuran ditentukan dengan jarak 5 dan 25 meter ini dikarenakan jarak jangkauan terjauh $40-50$ meter, selebihnya data akan loss. Dari hasil pengukuran ini didapat bahwa pengukuran pada jarak 5 meter dari letak Wifi pada masing masing ruangan menghasilkan sinyal yang baik yaitu Excelent ini dikarenakan tidak adanya 
penghalang seperti dinding atau tembok. Sedangkan untuk pengukuran dengan jarak 20 25 meter hasilnya berupa angka kekuatan sinyal yang bervariasi, tetapi masih dikategorikan baik. Berdasarkan hasil pengukuran dalam penelitiandilakukan beberapa perubahan letak Access Point dan selain itu hasil dari pengukuran dapat dirancang kembali (redesain) jaringan WLAN yang baru yang diharapkan dapat meningkatkan kualitas jaringan WLAN pada Dinas Pendidikan Kayuagung.

\section{DAFTAR PUSTAKA}

[1] Z. Saharuna, R. Nur, "Desain Jaringan WLAN Berdasarkan Cakupan Area dan Kapasitas," Jurnal Infotel - Informatika Telekomunikasi, 2016, p. 115.

[2] Bruno dan Jordan. (2011). CCDA 640-864 Official Cert Guide. Pearson Education, Inc. Indianapolis. https://sk1f3r.ru/wpcontent/uploads/2012/12/Bruno-A.-JordanS.-CCDA-640-864-Official-Cert-Guide-4thEdition-2011.pdf. Diakses pada tanggal 5 maret 2019.

[3] D. Agus Virgono,"Analisa Pengaruh Besar Area Hotspot dan Interferensi Pada WLAN IEEE 802.11b," Jurnal Penelitian dan Pengembangan TELEKOMUNIKASI, 2009, p. 4-9.

[4] Broadcom 2003, IEEE 802.11g The New Mainstream Wireless LAN Standard.

[5] Siyamta, 2013, Teknologi Jaringan Wireless.

[6] Andren, Carl, 1997, A Comparison of FHSS and DSSS Modulation for IEEE 802.11 Aplication at $2.4 \quad \mathrm{GHz}$, Harris Semiconductor, Palm Bay Florida.

[7] R. Munadi, M. Nasution, "Analisis Perbandingan Kualitas Jaringan Wireless LAN (WLAN) dengan Menggunakan Antena Eksternal Yagi 2,4 GHz dan Grid 2,4 GHz," Seminar Nasional dan Expo Teknik Elektro, 2015, p. 1-6.

[8] T. Arinto, "Implementasi Wireless Local Area Network dalam RT/RW Net," Jurnal
Teknologi Informasi DINAMIK, 2009, p. $152-157$.

[9] Enterprise, Jubilee, Rahasia Menjadi Jago Download. Elex Media Komputindo: Jakarta, 2010

[10] Sofana, Iwan, Membangun Jaringan Komputer". Informatika: Bandung, 2011

[11] Winarno, Edy, Ali Zaki dan SmitDev Community, Membuat Sendiri Jaringan Komputer. Elex Media Komputindo: Jakarta, 2013 